\title{
In Vitro Cytotoxic Study and Detection of Apoptosis on Breast Cancer Cell lines MDA-MB 231 after Exposed to Azadirachta Indica A. Juss (neem) Extract
}

\author{
Dessy Arisanty
}

\begin{abstract}
Abstrak
Suatu senyawa obat dapat menjadi kemoterapi kanker adalah dengan cara menskrining terlebih dahulu tumbuhan obat yang berpotensi sebagai obat antikanker. Salah satunya adalah tanaman obat daun nimba (Azadirachta indica L.Juss) yang terbukti secara significant menyebabkan apoptosis pada beberapa jenis sel line kanker. Dalam penelitian ini, ekstrak ethanol dari A. indica dipelajari untuk melihat efeknya pada pertumbuhan sel kanker payudara manusia jenis MDA-MB-231 dengan menggunakan tes untuk proliferasi yaitu MTT assai dan untuk mengetahui perubahan morphologi dari apoptosis selnya dengan menggunakan TUNEL assay Ekstrak daun nimba (A. indica) dapat menurunkan keberadaan jumlah sel kanker dengan cara menghambat perkembangan daripada sel tersebut dan menginduksi proses apoptosis pada sel kanker tersebut. Hasil pemeriksaan MTT assai didapatkan nilai IC50 nya adalah $55 \mathrm{ug} / \mathrm{mL}$. Kematian MDA-MB231 sel yang disebabkan oleh ekstrak daun nimba (A.indica) ditemukan melalui mekanisme apoptosis yang secara morfologinya menunjukan ciri ciri dari kematian secara apoptosis seperti kondensasi dari nucleus, membrane nukleus yang melebur dan akhirnya terjadinya fragmentasi dari DNA. Analisis struktur dalaman sel juga mengungkapkan karakteristik apoptosis yaitu marginasi dari kromosom yang disertai dengan fragmentasi DNA dan selanjutnya akan terbentuk badan apoptotik pada sel kanker yang diinkubasi dengan ekstrak tersebut. Pada penelitian ini juga dijumpai peningkatan jumlah sel apoptosis dari hari 1 sampai hari 3 inkubasi oleh ekstrak nimba. Ekstrak ethanol A.indica mungkin mengandung senyawa bioaktif(s) yang menyebabkan kanker payudara MDA-MNB 231 mengalami kematian sel secara apoptosis. Penelitian lebih lanjut masih diperlukan untuk mengetahui mekanisme tumbuhan ini membunuh sel kanker MDA-MB 231.
\end{abstract}

Kata kunci: Studi In vitro, Azadirachta indica, apoptosis, TUNEL assay

\begin{abstract}
A screening is conducted on plants that have potential as anticancer is a promising way for discovering novel chemotherapeutic compound. A medicinal plant neem leaf (Azadirachta indica L.Juss) intake has been shown to induce significant levels of apoptosis in various cancer cells. In this present study, ethanol extract of Azadirachta indica was studied for its effects on growth in MDA-MB 231 human breast cancer cells using assays for proliferation (MTT assay) and mechanisme of cell apoptosis using TUNEL assay. Neem leaf extract decreased cell viability, inhibited cell proliferation, and induced cell apoptosis. Result of MTT assay was $55 \mu \mathrm{g} / \mathrm{mL}$ of neem remarkably reduced cell viability of MDA-MB 231 cells. MDA-MB231 cell death elicited by the extract was found to be apoptotic in nature based the indication of nucleus condensation, shrinkage of nucleus membrane and also DNA fragmentation which are a hallmark of apoptosis. In addition, ultrastructural analysis also revealed apoptotic characteristics which are the presence of chromatin margination and apoptotic bodies in the extract-treated cells. There was an increase in the number of apoptotic cells from day 1 to day 3 post incubation with neem extract. Thus, the results from this study strongly suggest that the ethanol extract of A.indica may contain bioactive compound(s) that caused breast carcinoma, MDA-MNB 231 cell death by apoptosis. It's needed to do advance research to know more deeply the mechanism this plant on breast cancer cell line MDA-MB.
\end{abstract}

Keywords:In vitro study, Azadirachta indica, apoptosis, TUNEL assay

Affiliasi penulis : Bagian Biokimia Fakultas Kedokteran Unand Korespondensi :Bagian Bioimia Fakultas Kedokteran Universitas Andalas Jl. Perintis Kemerdekaan No.94, Padang. E-mail: desrantius@gmail.com Telp: 0751-23233

\section{INTRODUCTION}

A fundamental approach of new discovery for anticancer drugs have been developed based on cellbase screening for antiproliferative effects that targeting the specific lesion in molecular and cellular in some variations form of cancer. Current legislation demands that new drugs such as herbal medicines, cosmetics, food additives or drugs go through extensive cytotoxic testing before they are released to the consumer. This usually involves a large number of animal experiments. ${ }^{1}$ Thus, plant as well as as extract, drug, semi-synthetic plant or plant derived compound have played an important role in development of clinically used anti-cancer agent. ${ }^{2}$
Measurement of toxicity in vitro is a purely cellular event whose toxic response by in vitro study may be measured by changes in cell survival or its metabolism. $^{2}$ Introduction of the multiwell plates revolutionized the approach to replicate sampling in tissue cultures. A number of in vitro assays are available for testing the response of human tumors to chemotherapeutic agents. Since nature has provided effective anticancer agents, medicinal plants have made progress in anticancer therapies such as for screening extracts, fractions or isolated constituents to test their ability to reduce cancer. ${ }^{3}$ A simple colorimetric assay was developed by Mosmann as a test for cell proliferation and cell survival. ${ }^{4}$ Furthermore, other workers have adapted and modified this test for the measurement of chemosensitivity and cytotoxicity on human malignant cell lines. This assay is called MTT assay. The MTT assay involves the ability of viable cells to convert a soluble tetrazolium salt, 3-4,5 dimethylthiazol-2,5 
diphenyltetrazolium bromide (MTT) into an insoluble formazan precipitate by the mitochondrial succinate dehydrogenase enzyme which are active in living cells. ${ }^{5}$ The MTT assay is a rapid, simple, inexpensive, versatile, quantitative and highly reproducible colometric assay for mammalian cell viability/metabolic activity and also useful on a large scale of mycotoxins screening assays. This method has been used in a number of laboratories and various modifications have been introduced. ${ }^{6}$

One well-known medicinal plant is Neem (AzadirachtaindicaA.Juss). AzadirachtaindicaA.Juss has been traditionally used in traditional Indian medicines, and is well known as a base formulated for pesticides in agriculture and is also believed to spur various biological activities such as antimicrobial effects, ${ }^{7}$ in vitro antiviral activities, ${ }^{8}$ insecticidal activities, and antibacterial agents. In the different study, the ethanolic extract of neem againts buccal carcinogenesis, skin carcinogenesis, prostate cancer, mammary carcinogenesis, gastric carcinogenesis, also B16 melanoma. A indica also has potentiate as chemo preventive capability by regressing the hepatocarcinogenesis induced by DEN/AAF carcinogen. ${ }^{9}$

The elimination of tumor cells by the induction of apoptosis has become an important and new approach in cancer therapy. Most of these bioactive substances in extract or fraction exert their cancer chemotherapeutic activity by blocking cell cycling progression and triggering apoptotic cell death. Therefore the induction of apoptosis in tumor cell lines has become an indicator of the tumor treatment response in employing a plant derivate-bioactive substance to reduce and control human mortality due to cancer. ${ }^{10}$ In apoptosis studies, organic compounds are sometimes used as apoptosis inducers. These agents include a variety of molecules, extracts or novel synthesized compounds. ${ }^{11}$ It is well known that some clinically used anticancer agents or drugs can induce apoptosis in cancer cells. Apoptosis is characterized by a series of typical morphological event, such as shrinkage of the cell and nucleus as well as condensation of nuclear chromatin into sharply delineated masses that become marginated against the nuclear membranes. This is followed by fragmentation of the nucleus into membrane-bound apoptotic bodies and rapid phagocytosis by neighboring cells. ${ }^{12}$

Morphological assessment is the standard method for identifying and quantifying apoptosis. Since apoptosis was formerly defined on morphological grounds, identification of apoptotic cells should be morphology-based. The gold standard for identification of apoptotic cells is ultrastructural evidence of chromatin condensation, the earliest characteristic morphological feature. However, although ultrastructural evidence of chromatin condensation is an excellent parameter with high reliability the costs of electron microscopy for this purpose are prohibitive because it is extremely labor intensive, and therefore it is not recommended for routine work. Therefore, The Terminal deoxynucleotidyltransferase (TUNEL) method is the most widely used technique, most probably because it is facilitated by commercial availability of special kits and because microscopic evaluation of the number of positive cells is not difficult. ${ }^{13}$ The TUNEL assay was used as an immunostaining technique to detect both apoptotic and viable cells. This fluorescent dyes were used to stain for condensed nuclei and the detection of fragmented DNA. In this assay, the presence of Terminal nucleotodyltranferase (TdT) enzyme catalyze incorporating fluorescein-12-dUTP to the $3-\mathrm{OH}$ end of the fragmented DNA. ${ }^{14}$

The aim of this section was to detection the cytotoxic potential of the neem extract on MDA-MB 231 cell lines by using the MTT-based assay and followed by TUNEL assay staining to confirm the apoptosis.

\section{MATERIALS AND METHODS}

Plant Materials :The leaves of Azadirachtaindica, A.Juss (Neem) were collected around Universiti Putra Malaysia (UPM) Serdang, Selangor. The leaves were washed thoroughly with tap water, rinsed with distilled water, and then dried in the oven at $40^{\circ} \mathrm{C}$ overnight. The dried leaves were grinded until fine powder and stored in an airtight container until further use.

Ethanolic Extract :An amount of 100 grams of dried leaves of $A$. indica were homogenized and soaked in $90 \%$ ethanol for three days. This step was repeated for another four consecutive days. On the fifth day, the mixture was collected and filtered using filter paper (Whatmann no.1). The solvent extract was collected and left evaporated in a rotary evaporator for 24 hours. Subsequently, the crude extract was freeze dried at $80^{\circ} \mathrm{C}$ for 24 hours. Finally, the extract was dried for 48 hours and resuspended in absolute ethanol until further use.

Culturing Cells :The MDA-MB-231 were obtained from American Type Culture Collection (ATCC, USA). These cell lines were maintained with RPMI-1640 (Gibco, USA) supplemented with $10 \%$ fetal calf serum, $100 \mathrm{IU} / \mathrm{mL}$ penicillin and $100 \mu \mathrm{g} / \mathrm{mL}$ of streptomycin (Gibco, USA). The cells were cultured in $25-\mathrm{cm} 2$ flasks (Nunc, Denmark) and incubated in a $\mathrm{CO}_{2}$ incubator (Sanyo, Japan) with $5 \% \mathrm{CO}_{2}$ at $37^{\circ} \mathrm{C}$.

MTT Assay :The viability of the cells was determined by using an MTT assay. Exponentially growing cells were harvested, counted by using a haemocytometer, and diluted with medium yielding a concentration of $1 \times 10^{5}$ cell. $\mathrm{mL}^{-1}$. From this cell suspension, $100 \mu \mathrm{L}$ were pipetted into 96-well microtiter plates (Nunc, Denmark) and incubated for 24 hours in a $\mathrm{CO}_{2}$ incubator with $5 \% \mathrm{CO}_{2}$ (Sanyo, Japan) at $37^{\circ} \mathrm{C}$. A fresh medium was added to make up the final volume of $200 \mu \mathrm{l}$ on each well. The plates were incubated at $37^{\circ} \mathrm{C}$ in a $5 \% \mathrm{CO}_{2}$ incubator (Sanyo, Japan) for 96 hours. Then, $20 \mu \mathrm{L}$ of MTT reagent (Roche, USA) was added into each well. The plates were incubated again for 4 hours in a $\mathrm{CO}_{2}$ incubator at $37^{\circ} \mathrm{C}$. After that, 100 $\mu$ Lsolubilization buffer solution (Roche, USA) was added into each well. The cell then left overnight in a $\mathrm{CO}_{2}$ incubator at $37^{\circ} \mathrm{C}$. Finally, the absorbance was evaluated using with an ELISA microtiter plate reader at $513 \mathrm{~nm}$ (Antoz, LX 2200).

Culturing Cell Lines for TUNEL Assay :The cells were grown in a $25 \mathrm{~cm}^{2}$ flask (Nunc, Denmark) until $100 \%$ confluence, trypsinized and counted. Specific cell culture media for each cell lines was added to get a concentration of $1 \times 10^{5}$ cells $/ \mathrm{mL}$. From this, $500 \mu \mathrm{L}$ was pipetted and grown on a four chambered slides (LabTek, USA). The cells were incubated for 24 hours in a humidified incubator at $37^{\circ} \mathrm{C}$. After 24 hours, the old media in each well were removed and 
replaced with fresh cell culture media. Finally, the $\mathrm{EtOH}$ extract of A.indica (Neem was added in each well according to the $\mathrm{IC}_{50}$ concentration obtained from the MTT assay.

Detection of Apoptotic Cells Using TUNEL Assay :Detection of apoptotic cells was done by using an Apoptosis Detection System, Fluorescein (Promega, USA). The MDA-MB-231 were previously grown on chamber slides (LabTek, USA) and were treated with EtOH extract of neem. After 24, 48 and 72 hours postinoculation, the slides were proceed to TUNEL assay and immediately viewed under fluoresecent confocal microscope (CLSM Biorad 1024).

Quantification of Apoptotic Cells :Quantification of the apoptotic cells was done by using fluorescent confocal microscope.

\section{RESULT}

\section{Cytotoxic Effect of neem}

The ethanolic extract of $A$. indica was displayed the cytotoxic effect on MDA-MB 23 with $\mathrm{IC}_{50}$ values of 55 $\mu \mathrm{g} / \mathrm{mL}$.

\section{Cytotoxic Effect Neem on MDA-MB 231 Breast Cancer Cell}

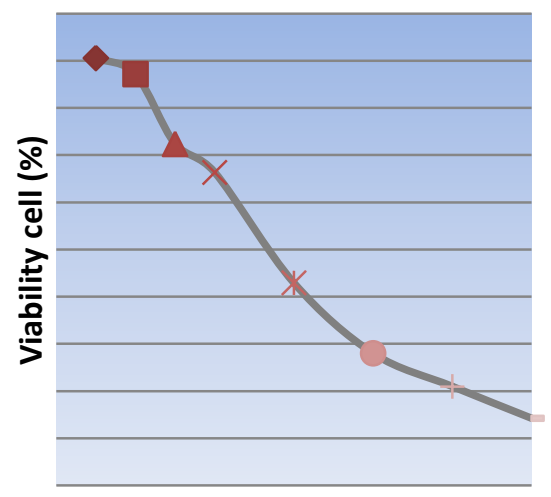

Concentration $\mathrm{ug} / \mathrm{mL}$

Figure 1: The effect of ethanolic extract of $A$. indica on MDA-MB 231. Cells were plated with $1 \times 10^{5}$ cells per well in 96-well culture plates. After 72 hours incubation at $37^{\circ} \mathrm{C} .1 \mathrm{C}_{50}$ of $55.0 \mu \mathrm{g} / \mathrm{mL}$ were obtained for MDA-MB-231.

\section{Quantification of Apoptotic Cells}

The labeled slide control and treated with extract of A.Indica (neem) were viewed under a confocal microscope (Figure 2 and 3 ). The number of viable (labeled red) and apoptotic cells (labeled green) were quantified and the percentages of apoptotic cells were calculated. Table 1 shows the percentage of apoptotic cells for MDA-MB 231 treated with extract of A.indica (neem). On day 1, the number of apoptotic cells of MDA-MB 231 was $29.33 \%$ while the number increased on day 2 and day 3 with value of $52.57 \%$ and $67.27 \%$, respectively.
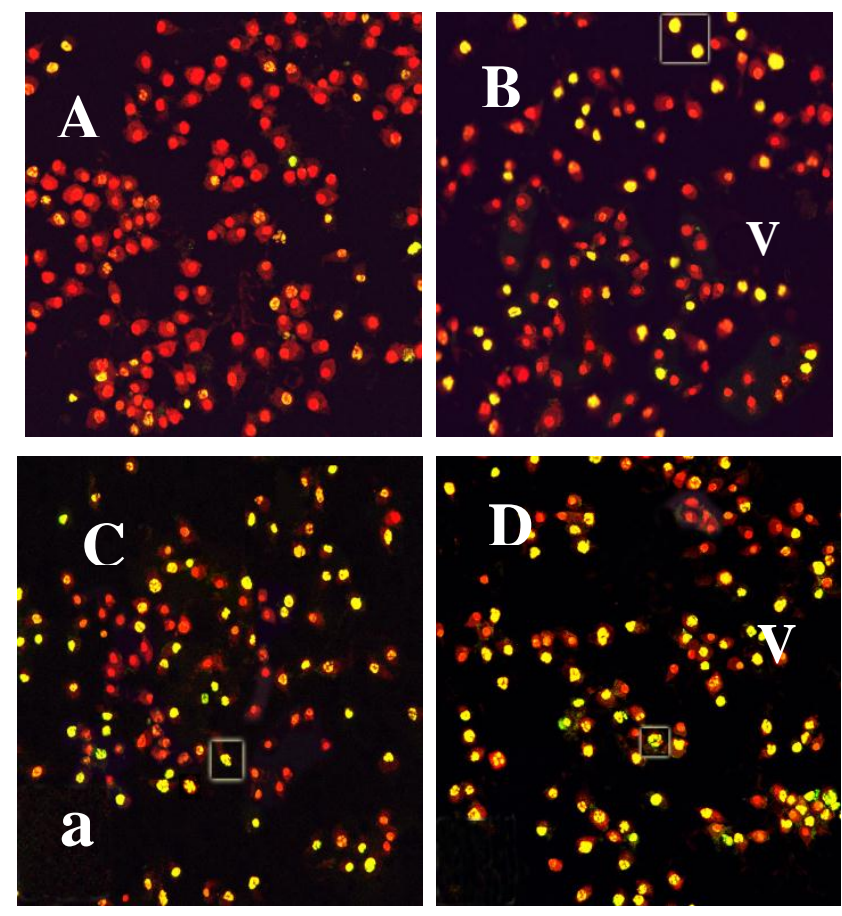

Figure 2 : Confocal micrographs of control and treated of MDA-MB 231 with ethanol extract of $A$. indicaA.Juss (neem) stained with TUNEL technique. : (A) control (B-D) treated at day 1 (B) day 2 (C) and day 3 (D). Cells were double-stained with fluorescent 12-dUTP (FITC) and propidium iodide (PI). Viable (v) cells show red to orange nuclei, whereas apoptotic cell (a) cells show yellow to green nuclei. Mag 400x

Table 1 : Quantification of apoptotic cells by percentage of apoptotic cells versus time Dependence

\begin{tabular}{cllll}
\hline \multirow{2}{*}{ Cells } & \multicolumn{3}{c}{ Percentage (\%) of apoptotic cells } \\
\cline { 2 - 4 } & Day 1 & \multicolumn{1}{c}{ Day 2 } & Day 3 \\
\hline MDA-MB 231 & 29.33 & \pm & $52.57 \pm 2.16$ & $67.27 \pm 2.75$ \\
& 1.03 & & & \\
\hline
\end{tabular}

\section{Morphological Apoptosis MDA-MB 231 Stained by TUNEL Technique}

The control of MDA-MB 231 cell lines was labelled red (Fig $3 A$ ) indicating the viable of cells. The treated MDA-MB 231 cells were also labeled red to orange which were indicating the viable of cells. The apoptotic cells were indicated by with yellow to green labels (Fig. 3B-D). In figure 3 shows the morphology of apoptosis on MDA-MB 231 cell lines. Figure 3B shows that condensation of nucleus, nucleus membrane was blebbing (figure $3 \mathrm{C}$ ) and fragmentation of nucleus shows at figure 3D. 


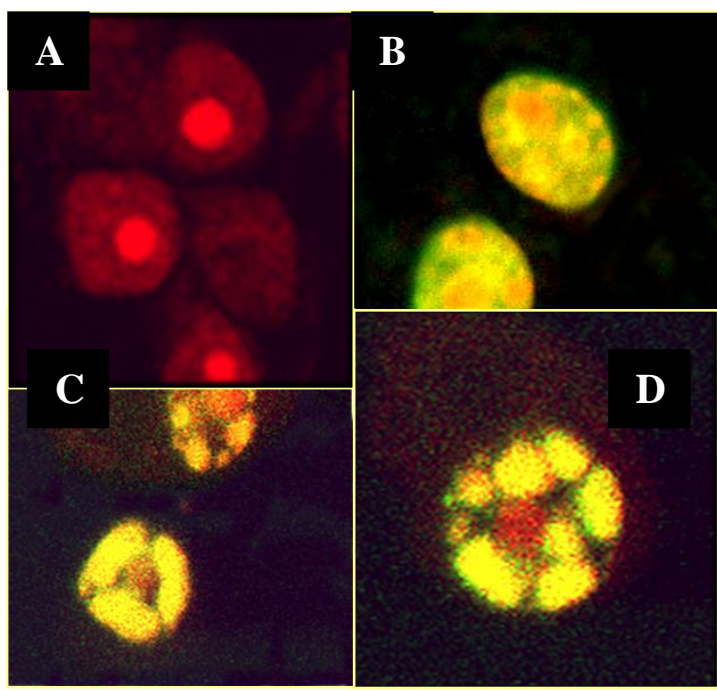

Figure 3 : Confocal microscopy of apoptosis morphology on MDA-MB 231 stained by TUNEL

\section{DISCUSSION}

The anti-proliferative effects of neem extract have been studied on various type of cell lines the screening was done by MTT assay. MDA-MB-231 was one of cells that killed effectively by neem extract. The MTT (3-[4, 5-dimethylthiazol-2-4I]-2, 5-diphenyl tetrazolium bromide) assay is a non-radioactive colometric assay to measure cell cytotoxicity and proliferation or viability of cells. MTT is yellow waterinsoluble dark, metabolically active cells are able to convert the dye to water -insoluble dark blue formazan by reduction cleavage of the tetrazolium ring. ${ }^{4}$ Therefore, testing of herbal agents in vitro on cancer cell lines to understand their mechanism of action may be helpful to enhance their effectiveness and prevent their undesirable effect.

In this study, extraction of AzadirachtaindicaA.Juss (neem) was conducted to determine its cytotoxic on MDA-MB 231. The study demonstrated that the ethanolic extract of neem displayed the cytotoxic effect on MDA-MB 231 cell lines. It has been reported that ethanolic extracts are normally used for anticancer screening because it is believed than the polar compounds were mostly responsible for claimed of isolating anticancer properties. ${ }^{15}$ As mentioned formerly, the ethanolic extracts of neem showed significant cytotoxic activities towards MDA-MB 231 may be due to the presence of limonoid in neem plant. Recently, it has been postulated that limonoids have high anti-cancer potential. ${ }^{16}$ Numerous studies have reported the usage of neem as an anticancer agent. Recently a study by Rathindranath and Uthpala found that neem leaf extract mediated immuneactivation which causes prophylactic growth inhibition of Murine Erlich carcinoma and B16 melanoma. ${ }^{17}$ Other than the leaves, polysaccharides isolated from neem barks, demonstrated anti-tumor effects and neem seed was reported to be cytotoxic to some tumor cell lines. ${ }^{18} \mathrm{~A}$ variety of other limonoids some of which are cytotoxic to N1E-115 neuroblastoma (mouse), 143B.TK osteosarcoma (human) and Sf9 cultured cell lines. The most potent of these limonoids is nimbolide with an $\mathrm{IC}_{50}$ ranging from 4 to $10 \mu \mathrm{M}$ and averaging $6 \mu \mathrm{M}$ for these cell lines. ${ }^{16}$

Further experimental insight into the mechanism of neem extract action towards MDA-MB 231 cells, has been acquired to confirm apoptotic cell death through morphological studies. Apoptosis is a cellular suicide or programmed cell death that is mediated by the activation of an evolutionarily conserved intracellular pathway. It is clearly seen that in MDA-MB 231 cells apoptosis process (figure 3) showes nucleus cell condensation, plasma and nuclear membrane blebbing, chromatin condensation, and formation of DNA strand break which indicated a early stage to form an apoptotic bodies. The main aim of all anti-cancer strategies is to eliminate tumor cells where the induction of apoptosis as like as a normal cell death. And also by the pharmacologically was preferred form of cell growth inhibition rather than through the necrosis process onto cells.

Until now a days, the microscopy has been the gold standard for the most precise detection of apoptosis morphology. With this technique, the whole process of apoptosis can be observed and evaluated based on the original morphological criteria by Wyllie et al. ${ }^{19}$ It was described that the convolution of plasma membrane and blebbing of cells were characteristic of apoptosis because DNA strand breakage is normally observed in apoptotic cells and is a definitive specific characteristic of apoptosis. Thus, TUNEL assay is better method to provide specific information about DNA strand breakage, a rapid phenotypic identification of individual apoptotic cells. In this study, the confirmation of apoptosis pathway displayed on MDAMB 231 cell lines. The treated cells were incubated with fluorescein-12-dUTP in the presence of TdT Enzyme. Fluorescein-12-dUTP labeled DNA strand break which was incorporated at the $3^{\prime}-\mathrm{OH}$ ends of fragmented DNA, resulting in green fluorescence within the apoptotic cells. After the enzymatic labelling procedure was completed, the cells were counterstained with propidium iodide, then the combination of two filters was featured as yellow to green colour

It is well known that apoptosis is concerned of changes that occurs in the nucleus which are featured as compaction and segregation of nuclear chromatin followed by DNA fragmentation. An early observation concerning apoptosis in this particularly research was that the cell entered apoptosis by characterization of changes in nuclear shape and in its organization. The phenomenon of a nuclear disintegration during apoptosis can be used as a marker to detect cells undergoing in an apoptosis process ${ }^{19}$. In this study, observation of the early stages of apoptosis was accompanied by convolution of nuclear or chromatin condensation. Chromatin condensation caused condensation of the cytoplasm. Somehow the nucleolus was clearly broke apart but the nucleus membrane was still intact. Furthermore, with the ethanolic extract of neem, the fragmentation of DNA as detected. While the apoptotic process continued, the nucleus and nucleus membrane began to be fragmented into many small bodies, called apoptotic bodies. Early fragmentation by collapsed nucleus frequently breaks into spheres. ${ }^{19}$ These features were corresponded to be as a last stage of apoptosis. In apoptosis morphology described the process of how a nucleus breaks up into several membrane-bound fragments. Some of that fragment contain of organelles (red/orange stained) instead of nuclear fragments (yellow). This characterization could be seen in this study. DNA fragmentation started at day 2 on MDA-MB 231. From all of the reported features, it was confirmed that ethanolic extract of neem induced apoptosis on MDA-MB 231 cells. This study also consistent with other experiment tant ethanolic extract 
of neem has been shown to cause cell death of prostate cancer cell(PC-3) by inducing apoptosis. ${ }^{20}$ However, quantification of apoptosis has generally relied on the TUNEL assay and most commonly used technique in fixed tissues and adherent cells. ${ }^{21}$ It takes advantage of the multiple free DNA ends generated by activated endonucleases to insert labeled dUTP that can be detected later by fluorescence microscopy or confocal microscopy. Quantification of apoptosis cells revealed that in MDA-MB 231 cells lines, the percentage of apoptotic cells increased from day 1 to day 3 post-inoculation. This fact indicated that there was a significant correlation between prolonged incubation times with the number of apoptotic cells. The findings of this study coincide with previous work on MCF-7 cells treated with ethanolic extract of A.indica. $^{22}$ The feature of apoptotic cell was well demonstrated by using AO/PI staining, as this was the first time TUNEL assay was carried out on breast cancer cell lines. Finally, it is suggested that ethanolic extract of neem against MDA-MB 231 cells inducing by apoptosis.

The present results, together with previous studies, suggest that neem leaf extract has great potential as an anticarcinogenic agent. In general, the beneficial effect of plant products such as neem, may be attributable to one or more phytochemicals including antioxidants, phenolic compounds and other substances. It is likely that neem leaf mediates the chemopreventive effects. Due to a lack of toxicity and ubiquitous distribution in nature, neem leaf may be regarded as a valuable plant source for use in traditional medicine and modern drug development.

Acknowledgment : Author gradefully thank you to my supervisor and co-supervisor, biomedical laboratory of Medical and Health Science Faculty and Imaging Microscopy Unit, Bioscience Institute, University Putra Malaysia.

\section{References}

1. Frank MB. Evaluation of anticancer drug discovery and the role of cell-based screening. Journal of the National Cancer Institute. 2002; 94: 78-9.

2. Ratnakaram ST, Bibhukalyan PN. Anticancer property of plant product. International Journal of Research in Ayurveda \& Pharmacy. 2011; 2(1): 111-3.

3. Holts, Oredsson SM. Comparison of three cytotoxicity tests in the evaluation of the cytotoxicity of a spermine analogue on human breast cancer cell lines. Toxicology In Vitro. 2005; 19: $379-87$

4. Mosmann. Rapid colorimetric assay for cellular growth and survival: Application to proliferation and cytotoxicity assays. Journal of Immunological Methods.1983; 65: 55-63.

5. Twentyman PR, Luscombe M. A study of some variables in a tetrazolium dye (MTT) based assay for cell growth and chemosensitivity. Journal Cancer. 1987; 56: 279-85.

6. Weyermann J, Lochmann D, Zimmer A. A Practical note on the use of cytotoxic assay. International Journal of Pharmaceutics. 2005; 288: 369 - 76.

7. Cetin Y, Bullerman LB. Cytotoxicity of fusariummycotoxins to mammalian cell cultures as determined by MTT assay. Food and Chemical Toxicology. 2005; 43 (5): 755-64.

8. Sai-Ram M, llavazhagan G, Sharma SK, Dhanraj SA, Suresh B, Parida MM, Jana AM, Kumar D,
Selvamurthy W. Anti-microbial activity of a new vaginal contraceptive NIM-76 from neem oil (Azadirachta indica). Journal of Ethnopharmacology. 2000; 71: 377-82.

9. Taha MME, Sia Wahab, Othman $F$, Hanachi $P$ Abdul AB, Alzubairi AS. In vivo anti-tumor effect of azadirachta indica in rat livere cancer. Res. J. Biol. Sci. 2008; 4: $48-53$.

10. Son YO, Kim J, Lim JC, Chung Y, Chung GH, Lee JC. Ripe fruits of Solanumnigrum L. inhibits cell growth and induce apoptosis in MCF-7 cells. Food and Chemical Toxicology. 2003; 41: 1421-28.

11. FumihikoK, Kazuhiko M, Masatada A. Apoptosislike cell death of human breast cancer cell line MCF-7 induced by Buprenorphine Hydrochloride. Life Sciences 2004; 75: 287-99.

12. Antti S, Karl P. Morphologic and biochemical hallmarks of apoptosis. Cardiovascular Research. 2000; 45: 528-37.

13. Rodriguez M, Schaper J. Apoptosis: measurement and technical issues. Journal of Molecular and Cellular Cardiology. 2005; 38: 15-20.

14. Rohwer F, Azam F. Detection of DNA damage in prokaryotes by terminal deoxyribonucleotide transferase-mediated dUTP nick end labeling. Applied and Enviromental Microbiology. 2000: 1001-6.

15. Tan ML, Sulaiman SF, Najimuddin N, Samina MR, Tengku Muhammad TS. Methanolic extract of pereskia bleo (kunth) DC (cactaceae) induces apoptosis in breast carcinoma T47.D cell line. Journal of Ethnopharmacology. 2004; 96: 287-97.

16. David, B. Limonoids: Pesticide to anticancer application from secondary metabolites of Rutaceae.and Meliceae. 2005. Tersedia dari URL: HYPERLINK: www. colostates.edu/Depts/Entomology

17. Rathindranath B, Utpala C. Neem (Azadirachta indica) leaf mediated immune activation causes prophylactic growth inhibition of murine ehrlich carcinoma and B16 melanoma. International immunopharmacology.2004; 4: 355-66.

18. Shimizu M, Takai M, Inore K, Tekeda T, Ogiwara $Y$. Antitumor polysaccharaides from Melia azadirachta barks extracts and their purification. Patent-Japan kokai Tokyo Kolo-01 275,602; 1998: 9-10.

19. Wyllie $A H$, Kerr JF, Currie AR. Cell death: the significance of apoptosis. International Review Cytology. 1998; 68: 251-306.

20. Kumar S, Suresh PK, Vijayababu MR, Arunkumar A, Arunakaran J. Anticancer effect of ethanolic neem leaf extract on prostate cancer cell line (PC3). J. Ethnopharmacol. 2006 ; 105 (1-2): 246-50.

21. Patwari P, Gaschen V, James IE, Berger E, Blake SM, Lark W, Grodzinsky AJ, Hunziker EB. Ultrastructural quantification of cell death after injurious compression of bovine calf articular cartilage. Osteoarthtritis and Cartilage.2004; 12 : 245-52.

22. Ajantha S. Evaluation of apoptosis inducing ability of neem (azadirachta indica) leaves extract on MCF-7 breast cancer cell line. Proc of $13^{\text {th }}$ Electron microscopy conference; 2001: 35-9. 